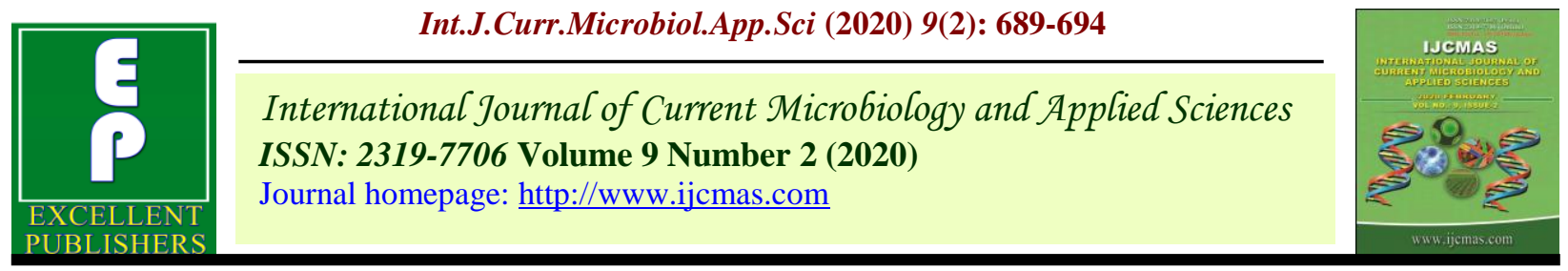

Original Research Article

https://doi.org/10.20546/ijcmas.2020.902.084

\title{
Growth in Area, Production and Productivity of Cotton Crop in Selected Districts of Karnataka, India
}

\author{
Ramesh $^{1 *}$, K. N. Krishamurthy ${ }^{1}$, G. S. Naveenkumar ${ }^{1}$, Narasamma $^{2}$ and G. Avinash ${ }^{1}$ \\ ${ }^{1} U A S$, GKVK, Bengaluru-560065, ${ }^{2}$ UAS, Dharwad-580005, \\ Karnataka, India \\ *Corresponding author
}

\section{A B S T R A C T}

\begin{tabular}{|l|}
\hline Ke y w or d s \\
Cotton, Area, \\
Production, \\
Productivity, \\
Growth rate \\
\hline Article Info \\
\hline $\begin{array}{l}\text { Accepted: } \\
\text { 08 January } 2020 \\
\text { Available Online: } \\
\text { 10 February 2020 }\end{array}$ \\
\hline \hline
\end{tabular}

Cotton is an important principal commercial fiber crop. It is one of the most leading and important cash crops in Indian economy. In the present study an attempt has been made using secondary data for forty six years (from 1970 to 2016) to understand the growth rates in area, production and productivity of cotton crop in Dharwad, Ballari and Raichur districts of Karnataka. The results revealed that area, production and productivity of cotton crop marked a significant increase in growth rate during the study period. In case of Dharwad district, increasing growth rate in area $(4.37 \%)$, production $(3.82 \%)$ and productivity $(3.01 \%)$ was observed. For Ballari district, increasing growth rate in area $(2.78 \%)$, production $(3.26 \%)$ and productivity $(2.99 \%)$ was observed. Whereas, in case of Raichur district, a decreasing growth under area $(-5.59 \%)$ and an increasing growth rate in production $(3.72 \%)$ and productivity $(3.26 \%)$ was seen.

\section{Introduction}

Cotton is the most essential natural fiber crop in the world for textile produce, accounting for about 50 per cent of all fibers used in the textile industry. It is more important than the various synthetic fibers, and it is grown all over the world in about 80 countries. It is unique among agricultural crops, because it is the main natural fiber crop, which provides edible oil and seed by-products for livestock feed. Further, it also provides income for hundreds of millions of people. It is one of the agro-industrial crops which are produced in both developing and developed countries. Cotton fibers are used in clothing and household furnishings. It has played an important role since the industrial revolution of the 17th century. Currently, it is an important cash crop especially for a number of developing countries at local and national levels (Gudeta and Egziabher, 2019). India is primarily an agriculture based country and its economy largely depends on agriculture. 
Agricultural growth is necessary not only for attaining high overall growth but also for accelerating the poverty reduction in a developing country like India (Pavitra et al., 2018). India cultivates the highest acreage under cotton in the world. It provides the basic raw material (cotton fiber) to the cotton textile industry (Rajan and Palanivel, 2018). It is the leading textile fiber in the world accounting for 35 per cent of the world fiber use. Cotton was first cultivated about 7,000 years ago, by the inhabitants of the Indus Valley Civilization. This civilization covered a huge swath of the north-western part of the Indian sub-continent, comprising today's parts of eastern Pakistan and north-western India (Mayilsami and Selvaraj, 2016). Cotton has been traditionally known as the backbone of nonfood crops of agricultural economy of India (Sharma, 2015). About 25 per cent of our country's Gross Domestic Product (GDP) comes from agricultural sector. Nearly 75 per cent of the country's population lives in villages and depends on agriculture (Parmar, et al., 2016).Cotton is an important principal commercial fiber crop. It is also known as 'White gold' or the "King of Fibers" due to its importance in agricultural as well as industrial economy throughout the world. Cotton is one of the leading and important cash crops in Indian economy (Mohammad et al., 2018). Cotton provides gainful employment to several million people in cultivation, trade, processing, manufacturing and marketing, etc. It serves vast handloom sector of the country. Apart from its use in textiles, cotton is also used as surgical lint and for various domestic purposes. Other plant parts of cotton are utilized in the manufacture of industrial products like paper, card board, blotting paper, etc. Cotton seeds have recently assumed greater importance as a source of edible oil. Thus, cotton plays a vital role in the Indian economy by contributing to human utilization in a number of ways. Cotton cultivation provides livelihood to millions of farmers. Their economic welfare heavily relies on cotton productivity. Cotton yarn, fabric, garment, etc. are dependent on the availability of cotton. Export of raw cotton and cotton products can earn foreign exchange for India. But India is not able to come up with satisfactory performance in cotton productivity in spite of having varieties of cotton and availability of technology. Its productivity is far below the major cotton producing countries. Demand for cotton textile is rising progressively all over the world. Being the first largest cotton producing area, India has an immense opportunity in the growth of the cotton textile industry and strengthening of Indian economy in the coming years (Mal and Pandey, 2013).

India is the only country in the world growing all the four cultivated species of cotton, viz., G. hirustum, G. arboretum, G. herbaceaum and $G$. barbadense. The maximum area has been covered by the hybrids (Samuel et al., 2013). Major Cotton producing countries are India, China, USA, Pakistan, Brazil, Australia, Uzbekistan, Turkey, Turkmenistan and Burkina (Rajan and Palanivel, 2017). In the recent period, cotton is gaining momentum in non- traditional areas such as Odisha, West Bengal and Tripura. India accounts for approximately 25 per cent of worlds total cotton area and 18 per cent of global cotton production (Kulkarni et al., 2017). India ranks first with respect to area and production and eighth rank with respect to productivity of cotton. Cotton in India occupies an area of 118.81 lakh hectares with a production of 345.82 lakh bales and productivity of $495 \mathrm{Kg} / \mathrm{ha}$. Cotton is cultivated in a majority of the states in the country. The ten major cotton producing states of India are Gujarat, Maharashtra, Telangana, Karnataka, Andhra Pradesh, Haryana, Madhya Pradesh, Rajasthan, Punjab and Tamil Nadu and accounts for more than 95 per cent of the area under cotton. In 
Karnataka area under cotton is around 7.5 lakh hectares which is 7 per cent of country's area. The production of crop is 28 lakh bales (around 4 per cent of country's production) while productivity is $653 \mathrm{~kg} / \mathrm{ha}$. The main cotton growing districts in Karnataka are Dharwad, Ballari and Raichur. India is unique among the major cotton growing countries because of the broad range of agro-climatic and soil conditions which permit cultivation of all varieties and staple lengths of cotton.

\section{Materials and Methods}

In the present study, major cotton growing districts of Karnataka viz., Dharwad, Ballari and Raichur were selected. In order to study the growth of cotton, secondary data pertaining to the area, production and productivity of cotton crop for the period of 46 years (from 1970-71 to 2015-16) was obtained from the Directorate of Economics and Statistics, Bengaluru.

\section{Statistical tools and models employed}

The Linear and compound growth rates for area, production and productivity were estimated from the time series data for the period from 1970-71 to 2015-16 collected from the Directorate of Economics and Statistics, Bengaluru. The following analytical tools were used to estimate the growth rates by using the method of ordinary least squares. The obtained data was compiled and analyzed for area, production and productivity of cotton in selected districts of Karnataka.

\section{Linear growth function}

Linear growth function is given by,

$Y_{t}=a+b_{t}+e_{t}$

Where, ${ }^{t}$ is the time in years, ${ }_{\text {tis }}$ the trend value, ${ }^{a}$ and $b$ are constants and $e_{t}$ is error term.

The linear growth rate is calculated by the formula,

Linear growth rate $(L G R \%)=\frac{b}{\bar{y}} \times 100$

\section{Compound growth function}

Compound growth function is given by,

$Y_{t}=a b^{t}$

Taking log on both sides, we have,

$\log Y_{t}=\log a+t \log b$

Where, ${ }^{t}$ is the time in years, $Y_{t \text { is }}$ the characteristic and $a$ and $b$ are parameters (Ramakrishna and Bhave, 2017).

The compound growth rate (CGR \%) is calculated by using the formula,

CGR $(\%)=($ antilog $b-1) \times 100$

The significance of the growth rates can be tested by applying student's t- test as

$\mathrm{t}=\frac{\mathrm{r}}{\mathrm{SE}(\mathrm{r})} \sim \mathrm{t}_{(\mathrm{n}-2)} \mathrm{df}$

Where, ${ }^{r}$ is the growth rate, ${ }^{n}$ is the total number of years under study and $S E(r)$ is the standard error of growth rate.

\section{Co-efficient of variation (cv)}

The co-efficient of variation (CV) has been worked out to find out the variation in the area, production and productivity of cotton crop in selected districts of Karnataka, over the years. 
$\mathrm{CV}=\frac{\text { Standard deviation }}{\text { Mean }} \times 100$

\section{Results and Discussion}

\section{Dharwad district}

An attempt was made to estimate the growth rates of area, production and productivity of cotton with the help of growth rate model explained in methodology. Growth rates for area, production and productivity of cotton crop for Dharwad district during the study period 1970-71 to 2015-16 are shown in Table 1. It was observed that the average area under cotton was 154.45 thousand hectares with a coefficient of variation of 51.97 per cent. The linear and compound growth rates during the study period were 3.43 and 4.37 per cent per annum respectively. It exhibited a positive significant trend for area under cotton for Dharwad district. The average production of cotton during the study period was 101.98 thousand bales with a coefficient of variation of 54.72 per cent. The linear and compound growth rates recorded for the study period were 3.09 and 3.82 per cent per annum respectively. The production of cotton showed a positive significant trend for Dharwad district. Regarding productivity of cotton in Dharwad district, the average productivity of cotton during the study period was $170 \mathrm{~kg} / \mathrm{ha}$, with a coefficient of variation of 44.32 per cent. The linear and compound growth rates were 2.82 and 3.01 per cent respectively. Thus, the productivity of cotton also had exhibited a positive significant trend during the study period in Dharwad district. As a whole, the growth rates for area, production and productivity were significantly increasing during the study period for Dharwad district. Similar growth rates were observed for area, production and productivity of cotton in Coastal Andhra region, Telangana region and Andhra Pradesh as a whole (Panasa, 2014).

\section{Ballari district}

Growth rates for area, production and productivity of cotton crop for Ballari district during the study period 1970-71 to 2015-16 are shown in Table 1. It was observed that average area under cotton was 70.46 thousand hectares with a coefficient of variation of 44.74 per cent. The linear and compound growth rates during the study period were 2.48 and 2.78 per cent per annum respectively. The area under cotton in Ballari district exhibited a positive significant trend according to linear and compound growth rates. The average production of cotton during the period was 64.52 thousand bales with a coefficient of variation of 84.59 per cent. The linear and compound growth rates recorded for the study period were 4.04 and 3.26 per cent per annum respectively. The production of cotton in Ballari district exhibited a positive significant trend. With respect to productivity of cotton in Ballari district, the average productivity of cotton during the period was $232.59 \mathrm{~kg} / \mathrm{ha}$, with a coefficient of variation of 48.57 per cent. The linear and compound growth rates during the study period were 2.96 and 2.99 per cent respectively. The productivity of cotton also had exhibited a positive significant trend during the study period in Ballari district. Hence, the growth rates for area, production and productivity were significantly increasing during the study period for Ballari district. Similar growth rates were observed for area, production and productivity of cotton for Coastal Andhra region, Telangana region and Andhra Pradesh as a whole (Panasa, 2014).

\section{Raichur district}

Growth rates for area, production and productivity of cotton crop for Raichur district during the study period 1970-71 to 2015-16 are depicted in Table 1. It was observed that the average area under cotton 
was 117.02 thousand hectares with a coefficient of variation of 85.48 per cent. The linear and compound growth rates during the study period were -5.50 and -5.59 per cent per annum respectively. The area of cotton in Raichur district exhibited a negative trend and was decreasing significantly during the study period. The average production of cotton during the period was 112.33 thousand bales with a coefficient of variation of 59.05 per cent. The linear and compound growth rate recorded for the study period were 3.71 and 3.72 per cent per annum respectively. The production of cotton exhibited a positive significant trend in Raichur district in case of linear and compound growth rates. Further, with respect to productivity of cotton in
Raichur district, the average productivity of cotton crop during the period was 241.22 $\mathrm{kg} / \mathrm{ha}$, with a coefficient of variation of 51.30 per cent. The linear and compound growth rates during the study period were 3.02 and 3.26 per cent respectively. Hence, the productivity of cotton also had exhibited a positive significant trend during the study period in Raichur district. Thus, it was observed that the growth rate for area was negative while high significant positive growth rates were observed for both production and productivity of cotton in Raichur district (Panasa, 2014) had showed the same pattern of growth for Rayalaseema region of Andhra Pradesh.

Table.1 Growth rates for area, production, productivity of Cotton crop in Dharwad, Ballari and Raichur districts

\begin{tabular}{|c|c|c|c|c|c|}
\hline \multirow{2}{*}{ Districts } & & Average & CV (\%) & LGR (\%) & CGR (\%) \\
\hline \multirow{2}{*}{ Dharwad } & Area & 154.45 & 51.97 & $3.43 * *$ & $4.37 * *$ \\
\cline { 2 - 6 } & Production & 101.98 & 54.72 & $3.09 * *$ & $3.82 * *$ \\
\hline \multirow{2}{*}{ Ballari } & Productivity & 170.00 & 44.32 & $2.80 * *$ & $3.01 * *$ \\
\hline \multirow{2}{*}{ Raichur } & Area & 70.46 & 44.74 & $2.48 * *$ & $2.78 * *$ \\
\cline { 2 - 6 } & Production & 64.52 & 84.59 & $4.04 * *$ & $3.26 * *$ \\
\cline { 2 - 6 } & Productivity & 232.59 & 48.57 & $2.96 * *$ & $2.99 * *$ \\
\hline & Area & 117.02 & 85.48 & $-5.40 * *$ & $-5.59 * *$ \\
\cline { 2 - 6 } & Production & 112.33 & 59.05 & $3.71 * *$ & $3.72 * *$ \\
\cline { 2 - 6 } & Productivity & 241.22 & 51.30 & $3.20 * *$ & $3.26 * *$ \\
\hline
\end{tabular}

** Significance at $1 \%$ level

In conclusion, a prudent attempt has been made in the present study to understand the trend in area, production and productivity of cotton crop in selected districts of Karnataka viz., Dharwad, Ballari and Raichur. The data was obtained from Directorate of Economics and Statistics, Karnataka for the period from 1970-71 to 2015-16. The present study has been made to evaluate the growth in area, production and productivity of cotton crop in selected districts of Karnataka. The results revealed that area, production and productivity of cotton crop marked a significant increase in growth rate during the study period. In case of Dharwad district, increasing growth rate in area, production and productivity was observed. For Ballari district, increasing growth rate in area, production and productivity was observed. Whereas, in case of Raichur district, a decreasing growth under area and an increasing growth rate in production and productivity was seen. 


\section{References}

Gudeta, B. and Egziabher, A.G. 2019, Cotton production potential areas, production trends, research status, gaps and future directions of cotton improvement in Ethiopia. Greener J. Agric. Sci., 9(2): 163-170.

Kulkarni, K.P., Jadhav, M.C. and Sharief, Z., 2017, Trend in cotton production in Nanded District of Maharashtra. Trends in Biosciences., 10(32): 6846-6848.

Mal, M. and Pandey, A., 2013, Instability and relative growth trend analysis of area, production and productivity of cotton crop in India. Int. J. Agric. Econ. and Management., 3 (2):35-42.

Mayilsami, K. and Selvaraj, A., 2016. Growth of cotton cultivation: A study in Tamil Nadu. Imperial J. Interdisciplinary Res., 2(11): 1-5.

Mohammad, D., Shiyani, R.L. and Ardeshna, N.J., 2018, Growth dimensions of long staple cotton area, production and yield in Gujarat, India. Int. J. Curr. Microbiol. App. Sci., 5(7): 2993-3005.

Parmar, R.S., Rajarathinam, A., Patel, H.K. and Patel, K.V., 2016,Statistical modeling on area, production and productivity of cotton (Gossypium spp.) crop for Ahmedabad Region of Gujarat State. J. Pure App. Microbiol., 10(1): 751-759.

Pavithra, N.L., Ashalatha, K.V., Megha, J., Manjunath, G.R. and Hanabar, S., 2018, Growth in area, production and productivity of food grains in Karnataka State, India. Int. J. Curr. Microbiol. App. Sci ., 7(8): 2532-2535.

Rajan, S.M. and Palanivel, M., 2017, Forecasting and growth model of cotton in Tamil Nadu State. Asian J. Agric. Extension, Econ. \&Sociology., 17(1): 15.

Rajan, S.M. and Palanivel, M., 2018, Application of regression models for area, production and productivity growth trends of cotton crop in India. Int. J. Stat. Distributions \& Applications., 4(1): 1-5.

Ramakrishna, G. and Bhave, M.H.V., 2017, Temporal variations in area, production and productivity of turmeric crop in India, Int. J. Res. in Business Management., 5(7): 83-90.

Samuel, J., Basavaraja, H., Puspanjali and Rejani, R., 2013, Trends in area, production and productivity of cotton across the major states in India, Int. $J$. Humanities, Arts, Med. \& Sci.,1(2): 97 102.

Sharma, A., 2015, Growth and variability in area, production and yield of cotton crop. Int. J. Agric. Innovations \& Res., 4 (3): 2319-1473.

Panasa,V., 2014,A study of temporal variations in area, production and productivity of cotton crop in three regions of Andhra Pradesh. M.Sc. (Agri.) Thesis (Unpub.), ANGRAU, Rajendranagar, Hyderabad.

\section{How to cite this article:}

Ramesh, K. N. Krishamurthy, G. S. Naveenkumar, Narasamma and Avinash, G. 2020. Growth in Area, Production and Productivity of Cotton Crop in Selected Districts of Karnataka, India. Int.J.Curr.Microbiol.App.Sci. 9(02): 689-694. doi: https://doi.org/10.20546/ijcmas.2020.902.084 